\title{
PCDHAC2 wt Allele
}

National Cancer Institute

\section{Source}

National Cancer Institute. PCDHAC2 wt Allele. NCI Thesaurus. Code C150289.

Human PCDHAC2 wild-type allele is located in the vicinity of $5 q 31.3$ and is approximately $46 \mathrm{~kb}$ in length. This allele, which encodes protocadherin alpha-C2 protein, is involved in cell-cell adhesion. 